\title{
Language Attitude and Urgency of Pakpak Dairi Language
}

\author{
Ida Basaria ${ }^{1}$, Parlindungan Purba ${ }^{2}$, Yulianus Harefa ${ }^{3}$ \\ ${ }^{1,2,3}$ Faculty of Cultural Studies, University of North Sumatra, Medan \\ Email:idal@usu.ac.id
}

\begin{abstract}
Local (native) languages in Indonesia and national language live in one umbrella organization and its growing, too, is in one umbrella organization, namely the Indonesian nation. In reality, the two languages can be said to be contradictions, because there is a desire for the national language to become a unifying language of every tribe, race, and culture in Indonesia. The uniformity of the use of national language in almost all areas of people can be contrary to the local language (mother tongue) they use as a colloquial language. The national language as the the other one that requires common use, it produces the first language communication in little by little began to erode. If this is still enforced, then the local language is less influential because few users can disappear not even known again in the future. It may form a bilingual another pattern in community, the understanding of the of Indonesian Language step by step replaces original one (local language). It is different if it is viewed from the view point of unity, then between regional and national languages can coexist harmoniously, simply to say, it dealt with local language. Then such things happen, there is no disappearance. It does not change local (native) languages, and in return. This paper wishes to study the language attitude of Pakpak Dairi language speakers as one of the local (native) languages in Dairi district of North Sumatra from the point of sociolinguistic ethnography and its relation to the vitality of this language.
\end{abstract}

Keywords: language urgency, language attitude, socio-ethnography

\section{INTRODUCTION}

In Indonesia, according to (Gunarwan, 2002), there are 169 local (native) languages that are threatened with extinction. And referring to a feature called by Grimes (2002), on the character of language serenity, BPD can almost be categorized into language groups that begin to erode. It can be observed through the naked eyes, that there is a tendency of attitude of the young generation of BPD people that are embarrassed. They are supposed uneducated people to use it. It connects native Indonesian language (hereinafter referred to as $\mathrm{BI}$ ) in daily interactions, both within their own environment and outside their environment .A language that is rarely used will gradually become a shifted (contaminated) language and die, as does the BPD. If it is used less frequently because of the dominance of Toba language, and also Indonesian language, it is possible that BPD will disappear from "circulation".

The people of BPD live in Dairi and West Pakpak districts, many of which are inhabited by ethnic immigrants from other ethnic groups. So automatically the people of BPD are bilingual or even multilingual. Bilingualism. In everyday interactions, besides using BI, also using other local languages (such as Batak language).

The use of two or more languages in a plural society is a natural phenomenon. Juvenile like to form multilingual in general unplanned by the olds. The condition of the bilingualism cannot be released with the term diglossia. It refers to a condition of society that recognizes and applies more languages for communications. So in situations of diglossia the use of two languages on society to be choice in the use. Events of diglossia indicate that division of functions of languages also gives meaning of the "high" type on of it or a "low" kind of it. High language types are used commonly who are prestigious. Because the low type is used in formal, by lay people to make relations. So in reality, this situation of diglossia actually happened in Indonesia and in Pakpak land in general. High function is carried by Indonesian language and low function is carried by local language (in this case BPD).

The national language as a second language, which is necessary for all social classes, can lead to the national language gradually eroding as a first language. If this still applies, the national language will be less powerful because fewer users will disappear or it will no longer be known at all in the 
future. Without a doubt, this is a great shame, because with the loss of local languages, local knowledge or traditional knowledge that is stored in the oral tradition of the language cannot be saved either. Apart from when viewed from the side of the unit, the local language and the national language can coexist in harmony. The use of language in the family environment should use local languages as a means of communication and interaction.

The following will be described the condition of the local language indicated is experiencing the language urgency. This exposure is focused on the language of Pakpak Dairi with consideration of this language began to be eroded by the Indonesian language, even eroded by other Batak languages in Dairi District of North Sumatra.

\section{LITERATURE REVIEW}

\subsection{Language Attitude}

Language attitude is a psychological event and is part of attitude (attitude) in general. The attitude of language is a mental position or feelings towards the language itself or the language of others (Kridalaksana. Harimurti, 2008).

Language attitudes can be observed through language behavior or speech behavior. But in this case also applies provisions that not every speech behavior reflects the attitude of language. Similarly, the attitude of language is not always reflected in speech behavior. Differentiated between language (langue) and parole (de Saussure, 1976), the discontinuity of the relationship between language attitudes and speech behaviors becomes even more obvious. Language attitudes tend to refer to language as a system (langue), whereas speech behavior is more likely to refer to concrete language usage (parole).

Edward (1985) says that attitude is only one factor, which is also not dominant, in determining behavior. Oppenheim (1976) can determine behavior on the basis of attitude. While Sugar (1967) based on his research gave a conclusion that the behavior is determined by four main factors, namely attitudes, social norms, habits, and possible consequences. Of the four factors it is said that the habit is the most powerful factor, while the attitude is the weakest factor. Thus, it is clear that attitude is not the only factor that determines behavior, but the most decisive behavior is habit.

\subsection{Medium And Division}

The use of two or more languages in a plural society is a natural phenomenon. Children naturally tend to educate themselves as bilingual or even multilingual without their parents' plans. According to Holmes (2013) and Grosjean (in Romain, 1989: vii), almost half of the world's population is bilingual and bilingual or bilingual in almost every country in the world. Furthermore, according to Romain, the monolingual community is in the so-called "one language" due to the diversity of social and regional forces. These can be found everywhere, not least in the regions of Indonesia.In a plural society, the language is the language of your ethnic group, one that is used in a broader setting outside of your clan, for example in the marketplace, and the other for communication purposes at school or in the office, the language is called polyglossy (see Willian, 2010)

Bilingualism in itself does not mean that one of the existing languages is depressed; the existence of two languages does not necessarily have to lead to the two languages "competing" or "fighting for their use". Competition arises when citizens begin to apply costbenefit analysis to the use and learning of the language. There is the possibility that citizens prefer one language over another. In other words, languages that don't get this preference will lose (start) competition and continue to be promoted.The language was not only brought into the home or family. But if the dominant language persists, and this happens, when the thinned diglosianya language is less competitive, it continues to be postponed, pinched, and eventually dies. If people leave it alone, it is ultimately inevitable that the dying language will die (see Gunarwan, 2002)

\subsection{Diglossia Events}

Diglossia is essentially a term used to refer to a state of society that recognizes and uses two or more languages to communicate between its members (a society that recognizes two or more languages for intra-social communication). (See Fishman.A, 1977), supra In diglossia situations, the use of two or more languages in the same society is "governed" by a policy of choice of the language to be used.

The events of diglossia suggest that the division of linguistic functions also gives the impression of a "high" type of language and a "low" type of language. High language types are used in situations that are considered more formal, by educated people and more prestige and prestige. While the low-key type of language is used in more informal situations, by the average person and as a means of public relations.

The division or separation of functions is generally associated with the so-called T (high) and R (low) languages; the diversity of the language $\mathrm{R}$ is rated as minor (minor). The use of informal languages such as family, neighbors, and clan is considered the domain in which the R languages are used, while the domain of religion, education, government, and the work environment is considered the domain. of formal use of language.

In a Diglossian society, each language has its own function, which is used by members of the community to express their will in accordance with the social norm of the linguistic society in question. The use of each language or variety of language is

determined by the behavior, attitudes and values that exist in the community, related to each language or variety of language used. The existence of different attitudes and points of view about each language is due 
to the fact that in a monolingual or multilingual society each language or variety of language is considered as its own "restrictions" (in the sense of function). When using and choosing language in relation to the concept of diglossia, it should be noted that the language usage domains formerly represented by the $\mathrm{R}$ language variety have been entered or replaced by the $\mathrm{T}$ language variety (diglossia leak), suggesting that language changes will begin.

\section{METHOD AND RESEARCH TECHNIQUE}

The method used in this research is descriptive qualitative research method with sociolinguistic approach. This study also uses a model of communication ethnography that specializes in the discovery of various communication patterns used by humans in a speech community.

The data collection tools used were questionnaires, interviews, testing, and participatory observation. The sample members who were the subjects of the study were asked to record the use of their language in the fields provided in the questionnaire. For the two sample groups, i.e. groups of children and parent groups, two separate questionnaires were available. For language use variables, score 1 is given for the 'always Indonesian' category, 2 for 'more Indonesian', 3 for 'as much Indonesian and local languages', 4 for 'more local languages', and 5 for category 'always local languages', while for research oflanguage attitude, two language questionnaires which contains some questions arranged in the scale of attitudes given to the sample to know their attitudes toward the language that existed in their language repertoire. Meanwhile, a guise technique (matched guise tecnique) is used to derive data on attitudes toward language speakers.

Data obtained through questionnaire, analyzed quantitatively. For each characteristic feature is calculated the mean number of language attitudes, using the Likert Scale or Likert technique, i.e. by asking the respondent to mark a position on the rating scale, e.g. 15 in accordance with the agreement or disagreement over a question. For questions relating to respondents' language attitudes, in the questionnaire are provided five choices of answers with the following weight (value). Value 5 for strongly agree, value 4 for agree, 3 for less agree, 2 for disagree, and 1 for strongly disagree. Based on the answers given by this respondent, it will be known the average value (mean) for each question. This average value is obtained by using the following formula.

$$
\frac{(n 1 \times 1)+(n 2 \times 2)+(n 3 \times 3)+(n 4 \times 4)+(n 5 \times 5)}{n 1+n 2+n 3+n 4+n 5}
$$

In this case $\mathrm{n} 1=$ the number of respondents who give a value of 1 for the corresponding characteristics, $\ldots \mathrm{n} 5=$ the number of respondents who give a value of 5 for the characteristics concerned. These average values are grouped into two groups; values of 1.0 - 2.5 are considered or interpreted to be disagreeable, and that is categorized as negative attitudes, while values of 2.6 to 5.0 are considered to be agreed and categorized as positive attitudes.

\section{RESULTS AND DISCUSSION}

Language Attitude or attitude of language is a mental position or feeling towards the language itself or the language of others. Based on that, language attitude is usually divided into two things, namely positive attitude and negative attitude.

A positive attitude is the attitude of enthusiasm towards the use of the language (the language used by the group / community said where he is). Conversely, if the traits have disappeared or weakened from one's self or from a group of members of the public, it means that a negative attitude toward a language has overwhelmed itself or that group of people. The lack of passion or encouragement to maintain the independence of the language is one of the markers of negative attitudes, that the loyalty of the language begins to weaken, which may continue to disappear altogether.

Below we will present a table on language attitudes of respondents to the language of BPD and Bahasa Indonesia (hereinafter referred to as BI).

\subsection{Attitude against Pakpak Dairi Language}

Of the 15 questionnaires tested to 40 respondents, almost all questions show good value, although in the range 2.04.7. It reflects that some respondents have a positive attitude and some respondents have negative attitudes toward BPD. The questionnaire will be discussed in the explanation below.

(1) Pakpak Dairi is an ethnic identity

(2) Pakpak Dairi is an intra-ethnic communication tool in the home environment The problem is used to determine the existence of BPD in the understanding of the respondents. Based on the questionnaires that have been filled by the respondents, it appears that the average value on the question number (1) reached 4.75 , while the problem number (2) reached 3.67. The respondents strongly agree that BPD is an ethnic identity and can be used as a means of community communication in the home and family environment. More clearly can be seen in the table below. 
Table 1. Attitudes about BPD as Ethnic Identity

\begin{tabular}{|c|c|c|c|c|c|c|c|}
\hline \multirow{2}{*}{$\begin{array}{c}\text { No. of } \\
\text { questions }\end{array}$} & \multicolumn{5}{|c|}{ Frequency } & \\
\cline { 2 - 8 } & SS & S & KS & TS & STS & Average & Attitude \\
\hline $\mathbf{1}$ & 30 & 10 & 0 & 0 & 0 & 4,75 & P \\
\hline & & & 2 & & & & \\
$\mathbf{2}$ & 7 & 13 & 0 & 0 & 0 & 3,67 & $\mathbf{P}$ \\
\hline
\end{tabular}

Table 2. Attitudes about BPD as Intra-group Relationships

\begin{tabular}{|c|c|c|c|c|c|c|c|}
\hline \multirow{2}{*}{$\begin{array}{c}\text { No. of } \\
\text { question }\end{array}$} & \multicolumn{5}{|c|}{ Frequency } & \multirow[b]{2}{*}{ Average } & \multirow[b]{2}{*}{ Attitude } \\
\hline & SS & $\mathbf{S}$ & $\mathbf{K S}$ & $\mathbf{T S}$ & STS & & \\
\hline 3 & 7 & 9 & 6 & 14 & 4 & 3 & $\mathbf{P}$ \\
\hline 4 & 5 & 12 & 9 & 11 & 3 & 3,1 & $\mathbf{P}$ \\
\hline
\end{tabular}

Table 3. Attitude on Language Usage in Language Events

\begin{tabular}{|c|c|c|c|c|c|c|c|}
\hline \multirow{2}{*}{$\begin{array}{c}\text { No. of } \\
\text { questions }\end{array}$} & \multicolumn{5}{|c|}{ Frekuensi } & \multirow[b]{2}{*}{ Average } & \multirow[b]{2}{*}{ Attitude } \\
\hline & SS & $\mathbf{S}$ & $\mathbf{K S}$ & TS & STS & & \\
\hline 5 & 2 & 5 & 17 & 13 & 3 & 2,8 & $\mathbf{P}$ \\
\hline 6 & 4 & 14 & 6 & 1 & 15 & 2,77 & $\mathbf{P}$ \\
\hline 7 & 2 & 5 & 11 & 13 & 9 & 2,45 & $\mathbf{N}$ \\
\hline 8 & 6 & 9 & 6 & 6 & 13 & 2,72 & $\mathbf{P}$ \\
\hline 9 & 2 & 9 & 18 & 5 & 5 & 2,87 & $\mathbf{P}$ \\
\hline 10 & 4 & 6 & 7 & 8 & 14 & 2,3 & $\mathbf{N}$ \\
\hline
\end{tabular}

Table 4. Attitudes about Response to BPD

\begin{tabular}{|c|c|c|c|c|c|c|c|}
\hline \multirow{2}{*}{$\begin{array}{c}\text { No. of } \\
\text { question }\end{array}$} & \multicolumn{5}{|c|}{ Frequency } & \multirow[b]{2}{*}{ Average } & \multirow[b]{2}{*}{ Attitude } \\
\hline & SS & $\mathbf{S}$ & KS & TS & STS & & \\
\hline 11 & 14 & 15 & 3 & 6 & 2 & 3,9 & $\mathbf{P}$ \\
\hline 12 & 17 & 10 & 7 & 6 & 0 & 3,9 & $\mathbf{P}$ \\
\hline 13 & 12 & 10 & 7 & 6 & 5 & 3,45 & $\mathbf{P}$ \\
\hline 14 & 18 & 6 & 8 & 8 & 0 & 3,85 & $\mathbf{P}$ \\
\hline 15 & 18 & 8 & 14 & 0 & 0 & 4,1 & $\mathbf{P}$ \\
\hline
\end{tabular}

Furthermore, the question below is a parameter showing the intra-technical relationship of Pakpak Dairi speakers in the home and family environment

(3) Pakpak Dairi language is able to convey ideas well in the social environment.

(4) Pakpak Dairi is used when talking to your friends or people around one ethnic (intraethnic)

Results of respondents concluded that the use of BPD is able to show good relationship among fellow speakers. It is shown in the table 2 .

The following problem (5-10) refers to the frequency of BPD use in accordance with the language event. The problem that is used to provoke it is:

(5) Pakpak Dairi is used when joking with one's ethnic friends

(6) Pakpak language is used when talking about (talking) with your friends or those around you in the family

(7) Pakpak Dairi is used to express anger

(8) Pakpak Dairi is used when joking with friends

(9) Pakpak Dairi is used when reading (counting) in the heart
(10) Pakpak Dairi is used when holding telephone conversations

The problem leads researchers to know the intensity of the use of Pakpak Dairi language of respondents in every language event, whether in story telling, reading, anger, joking, or when holding a conversation on the phone. Based on the problem, it is obtained good value which shows positive attitude of respondent to Pakpak Dairi language like the table 3

The last form of questionnaire in the questionnaires was the response of the respondents to the Pakpak Dairi language. It is described as hospitality, kinship, intimacy, love of ethnicity, and cultural richness that needs to be preserved. To get an overview of respondents to this, it is used in the following questions. (11) Pakpak Dairi language shows hospitality.

(12) Pakpak Dairi language shows kinship.

(13) Pakpak Dairi language shows intimacy / intimacy.

(14) The use of Pakpak Dairi language shows the love of ethnicity. 
(15) The use of Pakpak Dairi language shows the cultural richness that needs to be preserved and maintained.

Then the acquisition value for each of the above questions can be considered in the table 4 .

Based on all of the above explanations, it can be concluded that the attitude of the respondents to Pakpak Dairi language is a very positive attitude. The range of values determined for positive attitudes is $3.45-4.1$, and when it is concerned with the value of the respondents, it can be found that the values are close to perfect value. Thus, the respondent's attitude towards Pakpak Dairi language usage is quite positive.

Although it can be noted for question (11) found 3 respondents KS, 6 respondents TS, 2 respondents STS, BPD as a language that shows hospitality. Next on problem (12) found 7 respondents KS, 6 respondents TS BPD as a family language. Then there are $7 \mathrm{KS}, 6 \mathrm{TS}$ respondents, 5 STS BPD as a language that shows intimacy. Furthermore there are $8 \mathrm{KS}, 8 \mathrm{TS}$, BPD as a language that shows the love of ethnic. Finally, found 14 $\mathrm{KS}$, BPD as a cultural richness that needs to be preserved and maintained.

So although generally speaking, the attitude of speakers / respondents in general are good, it was found that some respondents / speakers have a negative attitude towards BPD.

\subsection{Attitude towards Indonesian Language}

Value acquisition shows that the attitude of respondents towards the Indonesian language tends to be positive, despite having a love of the mother tongue, namely BPD. Questionnaires are presented to determine the attitude towards the Indonesian language is also not different from the problem used to determine attitudes towards BPD. The issue will be discussed in the explanation below.

(16) Indonesian is a national identity.

(17) Indonesian language is a tool of community communication in formal education environment.

Table 5. Attitudes regarding BI (Indonesian Language) as a Nation's Identity

\begin{tabular}{|c|c|c|c|c|c|c|c|}
\hline \multirow{2}{*}{$\begin{array}{l}\text { No. of } \\
\text { questions }\end{array}$} & \multicolumn{5}{|c|}{ Frequency } & \multirow{2}{*}{$\begin{array}{c}\text { Avera } \\
\text { ge }\end{array}$} & \multirow[b]{2}{*}{ Attitude } \\
\hline & SS & $\mathbf{S}$ & KS & TS & STS & & \\
\hline 5 & 20 & 18 & 1 & 0 & 1 & 4,4 & $\mathbf{P}$ \\
\hline 6 & 2 & 10 & 7 & 1 & 20 & 2,3 & $\mathbf{P}$ \\
\hline 7 & 10 & 18 & 14 & 8 & 0 & 4,5 & $\mathbf{P}$ \\
\hline 8 & 5 & 29 & 5 & 1 & 0 & 4 & $\mathbf{P}$ \\
\hline 9 & 11 & 27 & 2 & 0 & 0 & 4,2 & $\mathbf{P}$ \\
\hline 10 & 5 & 10 & 2 & 13 & 10 & 2,6 & $\mathbf{P}$ \\
\hline
\end{tabular}

Table 6. Attitude on the Use of Indonesian in Language Events

\begin{tabular}{|l|l|l|l|l|l|l|c|}
\hline \multirow{2}{*}{$\begin{array}{l}\text { No. of } \\
\text { question }\end{array}$} & \multicolumn{4}{|l|}{ Frequency } & & \\
\cline { 2 - 6 } & SS & $\mathbf{S}$ & KS & TS & STS & Average & Attitude \\
\hline $\mathbf{1 6}$ & 25 & 15 & 0 & 0 & 0 & 4,6 & $\mathbf{P}$ \\
\hline $\mathbf{1 7}$ & 14 & 25 & 1 & 0 & 0 & 4,3 & $\mathbf{P}$ \\
\hline
\end{tabular}

From the table above it is shown that the attitude of respondents to BI is very positive; between 4.3 - 4.6. Respondents strongly agree that $\mathrm{BI}$ is used as a national identity and as a communication tool in formal meetings.

Furthermore, below is presented some sums or questions that refer to the frequency of use of BI in accordance with the events of the language.

The questions below are used as a tool for knowing what is meant.

(5) Indonesian is used when communicating in a formal context, such as when studying in a classroom.

(6) Indonesian is used when talking about (conversing) with your friends or those around you

(7) Indonesian is used to express anger in the educational / formal environment

(8) Indonesian is used when joking with friends in the education / formal environment

(9) Indonesian is used when reading (counting) in the heart of the environment

(10) Indonesian is used when having telephone conversations

The problem leads researchers to know the intensity of the use of Pakpak Dairi language of respondents in every language event, whether in storytelling, reading, anger, joking, or when making a conversation on the phone. Based on the problem, it is obtained good value which shows positive attitude of respondents towards BI, like the table below.

The last question form in the distributed questionnaire is a question of responses (concepts) of the respondents towards the Indonesian language. It is described as hospitality, kinship, intimacy, love of ethnicity, and cultural richness that needs to be preserved. More clearly it is shown in the following questions.

(11) Ability and proficiency in the Indonesian language shows intelligence / intelligence of a person.

(12) Good knowledge of Indonesian language indicates a person's high education.

(13) The use of Indonesian language shows confidence.

(14) The use of Indonesian language shows progress / codism.

(15) Good use of Indonesian means to assure a good position.

Then the acquisition value for each of the above questions can be presented in the table below. 
Table 7. Attitude on Response to BI

\begin{tabular}{|c|c|c|c|c|c|c|c|}
\hline \multirow{2}{*}{$\begin{array}{c}\text { No.of } \\
\text { questions }\end{array}$} & \multicolumn{5}{|c|}{ Frequency } & \multirow{2}{*}{$\begin{array}{l}\text { Ave } \\
\text { rage }\end{array}$} & \multirow[b]{2}{*}{ Attitude } \\
\hline & SS & $\mathbf{S}$ & KS & TS & STS & & \\
\hline 11 & 8 & 18 & 14 & 0 & 0 & 3,9 & $\mathbf{P}$ \\
\hline 12 & 8 & 13 & 17 & 2 & 0 & 3,7 & $\mathbf{P}$ \\
\hline 13 & 12 & 17 & 10 & 1 & 0 & 4 & $\mathbf{P}$ \\
\hline 14 & 8 & 21 & 11 & 0 & 0 & 3,9 & $\mathbf{P}$ \\
\hline 15 & 5 & 11 & 19 & 5 & 0 & 3,4 & $\mathbf{P}$ \\
\hline
\end{tabular}

Based on all of the above exposure, it can be concluded that the attitude of the respondents towards the Indonesian language is a very positive attitude. The range of values specified for positive attitudes is $2.6-4.7$, and when it is concerned with the scores of respondents, it can be found that they are near perfect values. Thus, the attitude of respondents to the use of Indonesian language is quite positive.

\subsection{Language Selection}

Language attitudes cannot be separated from language selection. Therefore, based on the questionnaires that have been distributed to the respondents, it was found that out of the ten questions presented, seven illustrate a positive attitude, while 4 of them show a negative attitude. It can be seen more clearly in the table below.

Table 8. Language Selection

\begin{tabular}{|c|c|c|c|c|c|c|c|}
\hline \multirow{2}{*}{$\begin{array}{c}\text { No.of } \\
\text { questions }\end{array}$} & \multicolumn{5}{|c|}{ Frequency } & \multirow{2}{*}{$\begin{array}{l}\text { Ave } \\
\text { rage }\end{array}$} & \multirow[b]{2}{*}{ Attitude } \\
\hline & SS & $\mathbf{S}$ & KS & TS & STS & & \\
\hline 1 & 2 & 2 & 15 & 16 & 5 & 2,5 & $\mathbf{N}$ \\
\hline 2 & 2 & 1 & 7 & 14 & 16 & 2 & $\mathbf{N}$ \\
\hline 3 & 3 & 1 & 7 & 14 & 16 & 2,1 & $\mathbf{N}$ \\
\hline 4 & 1 & 7 & 19 & 6 & 7 & 2,7 & $\mathbf{P}$ \\
\hline 5 & 8 & 12 & 14 & 8 & 8 & 3,1 & $\mathbf{P}$ \\
\hline 6 & 7 & 2 & 8 & 12 & 11 & 2,6 & $\mathbf{P}$ \\
\hline 7 & 8 & 5 & 10 & 9 & 8 & 2,9 & $\mathbf{P}$ \\
\hline 8 & 3 & 4 & 8 & 11 & 14 & 2,3 & $\mathbf{N}$ \\
\hline 9 & 18 & 9 & 7 & 1 & 5 & 3,9 & $\mathbf{P}$ \\
\hline 10 & 12 & 12 & 12 & 3 & 1 & 3,8 & $\mathbf{P}$ \\
\hline
\end{tabular}

With details of of questions as follows:

(1) Pakpak Dairi language you should use everyday to friends seetnik at home (family)

(2) Pakpak Dairi language you always use everyday to your friends seetnik if met outdoors?

(3) Pakpak Dairi language you prefer in conversation with your friends in your surroundings

(4) In your opinion, the Pakpak Dairi language feels more beautiful

(5) If you hum, Pakpak Dairi language you use

(6) If you grumble, Pakpak Dairi language you use

(7) If you are imagining, Pakpak Dairi language that you use
(8) With a close friend, Pakpak Dairi is the language you use most often when you're at home, at a friend's house, on the street, etc. at a time when talking about personal issues with a teammate.

(9) Pakpak Dairi language that you used when praying / pleading to God?

(10) Pakpak Dairi language most often used when sending short messages (SMS) to friends or people around you?

Based on the acquisition values in the table and the questions listed above it can be seen that the numbers (1), (2), (3) and (8) illustrate the negative attitude. It implies that respondents tend to choose to use Indonesian in daily conversations with their teammates at home / family environment. In addition, respondents also tend to choose to use BI when meeting with friends outside the house with the same ethnic. Also from the data exposure, it was found that respondents also tend to choose to use $\mathrm{BI}$ in storytelling or to talk about personal issues with close friends. Respondents' answers to the four questions that describe the selection of BPD, can be classified as a negative attitude. This means that in the informal realm and private conversations with friends of the same ethnic I friend familiar BPD has been replaced by BI. So the BPD began to be pushed by BI (or other local languages).

The respondent's responses to the questions (4), (5), (6), (7), (9), and (10) presented to measure language selection illustrate a positive attitude to BPD. The respondents chose to use BPD in conversation, humming, grumbling, fantasizing, praying / pleading to God, and sending short messages (SMS) to those around them. Thus, it concludes that respondents, i.e. respondents have a positive attitude towards the use and selection of Pakpak Dairi language as a colloquial language. This positive attitude is an attitude of enthusiasm towards the use of BPD. The love of the language is illustrated with a positive attitude, and the positive attitude is reflected in the intensity of the use of the BPD in everyday conversation. This also will be a form of defense of this language.

What is the relationship between the speaker's attitude to BPD's defense and urgency. There is a situation of passive language defense. Behavior related to BPD defense tends to be less inadequate with the speaker's attitude to BPD. Although members of the language community tend to agree on certain feelings and beliefs about BPD, there is a certain gap in the language community in terms of daily language behavior. Meanwhile, a group of community members maintains the use of BPD in a number of intracomplex interactions as reflections and feelings and beliefs on the language, other members of the community may not have the same incentive to do so. This can be seen from the still finding of respondents who do not agree with BPD as a language that shows hospitality (3 respondents KS, 6 TS, 2 STS, BPD as a language that shows hospitality.Then there are 7 respondents KS, 6 ressponden TS - BPD as kinship language). Then there are some speakers who do not 
agree with BPD as a language that shows intimacy (7 KS, 6 TS, 5 STS - BPD as a language that shows intimacy). Furthermore there are some speakers who do not agree that the use of BPD is showing the love towards Pakpak Dairi ethnic (8 KS, 8 TS - BPD as a language showing the love of ethnic). And found also speakers who do not agree that BPD needs to be preserved. (14 KS-BPD as a cultural treasure that needs to be preserved and maintained.)

So although generally speaking, the attitude of speakers / respondents in general is good, it was also found some respondents / speakers who have negative attitudes towards BPD.As a result, group members do not use the language in steady manner.

\section{CONCLUSIONS AND SUGGESTIONS}

The attitude of the speakers of BPD is quite positive. The positive attitude of the speakers of BPD is an attitude of enthusiasm towards the use of Pakpak Dairi language. The love of BPD is illustrated with a positive attitude, and the positive attitude is reflected in the intensity of selection of Pakpak Dairi language use in daily conversation. This will also be a form of language preservation as part of the culture as well as local wisdom.

However, some speakers also found negative attitudes toward BPD; because there are few speakers although the numbers are small) who strongly disagree with BPD as a language that shows hospitality. Also disagreed with BPD as a familial language, and argued that BPD is not necessary to be preserved. This indicates that the BPD has started to be easily pushed by BI (and other local languages around it).

This conclusion is reinforced by the discovery of speakers who tend to choose to use the BI in daily conversations with friends of the same ethnic at home / family or outside the house.

\section{ACKNOWLEDGMENTS}

The research team would like to thank the USU Research Institute for giving the trust to carry out this research. This article is part of the USU TALENTA research entitled: Ketergerusan dalam Kediglosiaan Bahasa Pakpak Dairi: Kajian Perspektif Gender . Youth for Fiscal Year 2019. No: 4167/UN5.1.R/PPM/2019 tanggal 01 April 2019

\section{REFERENCES}

[1] de Saussure, F. (1976). Course in General Linguistcs. The Library of The University of California Los Angeles, Philosophical Library.

[2] Edward, A. (1985). Technique of Attitude Scale. Appleton-Century-Crof.Inc.

[3] Fishman.J.A. (1977). Bilingualism in the Barric. India University.

[4] Grimes, B. F. (2002). Kecenderungan Bahasa untuk
Hidup Atau Mati secara Global (Global Language Viability): Sebab, Gejala, dan Pemulihan untuk Bahasa Bahasa yang Terancam Punah (B. K. Purwo (ed.)). Lembaga Bahasa Atmajaya.

[5] Gunarwan, A. (2002). Kasus-Kasus Pergeseran Bahasa Daerah:Akibat Persaingan dengan Bahasa Indonesia. Jurnal Linguistik Indonesia, 24(1).

[6] Holmes, J. (2013). In Introduction to Sociolinguistics. Routledge Group.

[7] Kridalaksana. Harimurti. (2008). Kamus Linguitik. Gramedia Pustaka Utama.

[8] Oppenheim. (1976). Questionaire Design, Interviewing, and Attitude Measurement. Printer Publisher.

[9] Willian, S. (2010). Pemertahanan Bahasa dan Kestabilan Kedwibahasaan pada Penutur Bahasa Sasak di Lombok. Jurnal Linguistik Indonesia, 28(1), 23-39. 